\title{
US and EC launch separate foundations to help Russians
}

Washington \& London. The US Congress and the European Communities have independently created foundations to support joint research projects with scientists in the former Soviet republics. Combined, the two foundations may spend as much as $\$ 20$ million annually on research, scientific conferences and travel, a tremendous amount in a region where a scientist can be supported for less than $\$ 2,000$ a year.

Earlier this month, Congress passed legislation creating the AmeRus Foundation, a nongovernment foundation whose initial \$25 million endowment was also approved as part of the 1993 military budget. The foundation expects to begin operations more quickly than a comparable government initiative, perhaps accepting applications as soon as the beginning of next year for joint projects between US researchers and those in the former Soviet republics. The foundation is modelled on one between US and Israeli researchers that was formed in 1977 and, like the USIsrael foundation, it will use an international peer-review committee to review applications.

Staff members of the House science committee chaired by US Representative George Brown (Democrat, California), who sponsored the legislation, say they were surprised at the success of the bill. Both the National Science Foundation and the State Department saw the foundation as competition for the US-Russian science institute that the administration has been trying to set up for almost a year (see Nature 355, 756; 1992). But it was helped by bipartisan support and the active involvement of $\mathrm{Al}$ Gore (Democrat, Tennessee and the Democratic candidate for vice-president).

Last week, the European Commission (EC) approved ECU4 million (US\$5.2 million) to start a similar foundation promoting science in the states of the former Soviet Union. Once operating, the EC foundation will fund joint projects with European researchers as well as travel, workshops and seminars. In January, EC ministers are expected to approve a budget for 1993; if it is deemed successful, the foundation will become part of the fourth Framework programme.

Although the current plan is for the EC foundation to be run by the government, EC lawyers are exploring ways to make the foundation a private corporation, incorporated in Belgium, which would bring it closer to its US counterpart and speed up a review process that could add months to the awarding of funds.

EC officials hope eventually to support around 5,000 researchers or group leaders, the majority in Russia, representing the top 5 per cent of the scientists in the former Soviet Union. The Russian governmentplans to supplement the grants awarded by both the EC and US foundations.

Christopher Anderson \& Ian Mundell

\section{Buyer shows a fine eye for science}

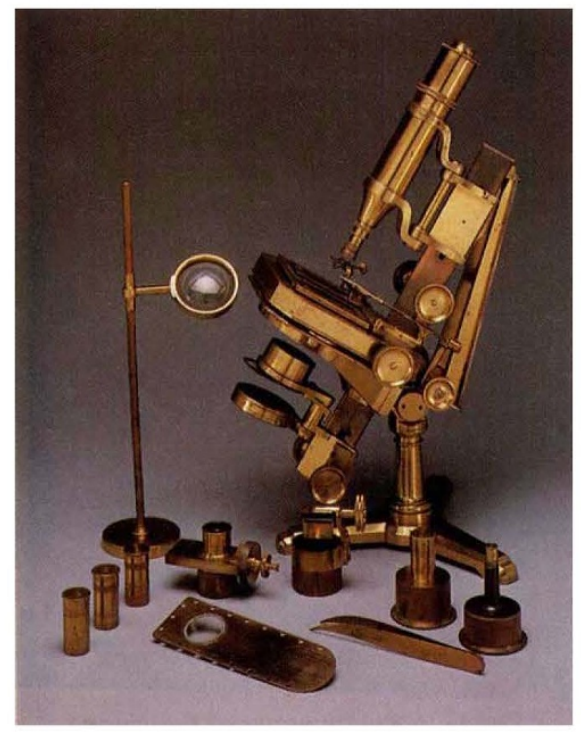

This 1842 Powell and Lealand compound monocular microscope fetched $£ 22,000$ in a Sotheby's auction earlier this month, a record at auction for a nineteenth-century microscope and well above the estimated sale price of $£ 6,000$ to $£ 9,000$. Auctioneers say that the market for scientific instruments, although quite healthy, has yet to interest the sort of investment buyers who sent art prices through the roof in the 1980 s. Collectors of scientific instruments tend to have an appreciation of the technical capabilities of what they buy, and particularly value items made or used by their inventors.

lan Mundell

\section{Scope and speed of NSF commission is criticized}

Washington. Add D. Allan Bromley and the members of an external scientific panel advising the president to the list of people unhappy with the National Science Foundation (NSF)'s Commission on the Future of NSF.

The NSF commission (see Nature 359 , 261 ; 1992) has become a target for researchers concerned that its report, due on 20 November, will suggest that NSF should cater more to industry. Their fear stems from comments made by Walter Massey, director of NSF, in an August letter announcing the formation of the commission, but the commission's first two meetings suggests that it has no such plans and, indeed, that it is eager to affirm NSF's role as the primary source of federally funded basic research.

Bromley, the president's science adviser, has a different bone to pick with the commission. He thinks it is overstepping its boundaries by examining overall federal policies towards science instead of confining itself to NSF. The former, not coincidentally, is part of the responsibility of the White House Office of Science and Technology Policy (OSTP), which Bromley directs.

Although the 1950 law creating NSF gave its advisory body, the National Science Board, the authority to look at national issues, Bromley says that NSF's first director, Alan Waterman, "deliberately avoided" such a broad mandate, choosing instead to strengthen the foundation. "What you're seeing is an attempt by the science board to reclaim that turf, and I think it's inappropriate", says Bromley.

Last week, at the same meeting in which Bromley made his comments, members of the President's Council of Advisors on Science and Technology (PCAST) questioned whether the 15-member commission could accomplish its task in such a short time (its report is due nine weeks after its first meeting). "How on earth can they come up with anything useful so quickly?" asked Mary Good of Allied-Signal Corporation, a former chair of the science board.

Massey says that he expects the commission "to assess the total federal environment" in the course of plotting NSF's future but that it is free to set its own agenda. The commission has no plans to meet OSTP officials or those from other federal science agencies.

William Danforth, chancellor of Washington University in St Louis and co-chair of the commission, says that the report "will leave lots of avenues unexplored" but that it is up to the science board to decide if additional analysis is needed.

Jeffrey Mervis 